\title{
TYPE SPECIMENS OF SPECIES OF DYNASTINI (COLEOPTERA: SCARABAEIDAE: DYNASTINAE) DESCRIBED BY J. L. LECONTE AND G. H. HORN
}

\author{
By JoNATHAN R. MAWDSLEY \\ Department of Entomology \\ Museum of Comparative Zoology \\ Cambridge, MA 02138 USA
}

\begin{abstract}
A lectotype is designated for Megasoma thersites LeConte (type-locality Cape San Lucas, Baja California) from the Leconte collection, Museum of Comparative Zoology. The holotype of Dynastes grantii Horn is preserved in the Horn collection, Museum of Comparative Zoology.
\end{abstract}

\section{INTRODUCTION}

The pioneer American coleopterists John L. LeConte and George H. Horn each described a single species of Dynastini. Given the popularity of scarabs, particularly dynastines, with collectors and the relative accessibility of the LeConte and Horn collections in the Museum of Comparative Zoology (MCZ), it is surprising that no previous workers were aware that Megasoma thersites LeConte was described from 8 specimens, none of which had originally been designated as a holotype. Hardy (1972:773) speculated that this species had been described from a single holotype male, but an examination of the LeConte collection and LeConte's original description (1861:336) clearly indicate that multiple specimens were used to describe this species. I have therefore designated a male specimen from the syntype series as lectotype.

The single species of Dynastini described by G. H. Horn, Dynastes grantii, was described from a single specimen from Fort Grant, Arizona, and the holotype of this species is in the Horn collection in the MCZ. I have provided bibliographies and brief diag-

Manuscript received 7 July 1993. 
noses for each of these species below. The keys provided by Endrödi (1985:633-643) should serve to separate these two species from related species.

\section{Megasoma thersites LeConte}

LeConte 1861:336; Horn 1894:337; Casey 1915:261 (Megasominus); Saylor 1948:358; Hardy 1972:772-773; Endrödi 1985:641, 643, pl. 38 f. 1.

Diagnosis: Length of males, inclusive of horns, 34-46 mm; length of females 34-37 mm; integument dark brownish-black, finely and densely punctate; elytral punctures larger, irregular, surrounding 4 indistinct longitudinal costae; integument more or less clothed with yellowish-white reclinate setae; male with 4 horns: a large recurved bifid cephalic horn; 2 short anteriorly-directed horns, one on either side of pronotal apex; and a single short bifid anteriorly-directed dorsal prothoracic horn; female lacking cephalic and prothoracic armature.

Materials: I examined 40 adult specimens, all ex MCZ: Cape San Lucas, Baja California (LECTOTYPE male, here designated (MCZ Type number 3781) + 3 male PARALECTOTYPES, 4 female PARALECTOTYPES, 1 male TOPOTYPE, 1 female TOPOTYPE); San Jose del Cabo, Baja California (2 males, 1 female); Santa Rosa, Baja California (4 males, 2 females); "Baja California" (2 males, 1 female); San Diego, [Baja?] California (4 males, 1 female); "California" (4 males, 3 females); no locality specified (5 males).

\section{Dynastes grantii Horn}

Horn 1870:78 (Dynastes tityus var.); Casey 1915:261; Endrödi 1985:636, pl. 36 f. 1 .

Diagnosis: Length of males, inclusive of pronotal horn, 50-67 $\mathrm{mm}$; length of females $39-51 \mathrm{~mm}$; integument dark brownishblack to greenish-grey, frequently with round brownish-black maculae, finely and sparsely punctate; head of males with a single elongate recurved dorsal horn with a distal dorsal tooth; pronotum of males with an elongate bifid anteriorly-directed horn bearing two short ventral horns and orange-yellow ventral pubescence; female lacking prothoracic and cephalic armature, similar to that 
of D. tityus (L.) but distinguished by geographic range (D. tityus ranges from NJ south to FL and TX) and by characters given by Endrödi (1985:636).

Materials: I examined 30 adult specimens, all ex MCZ: Fort Grant, AZ (HOLOTYPE male, MCZ Type Number 33536); Gila Co., AZ ( 1 male, 2 females); Jerome, AZ ( 3 males, 1 female); Phoenix, AZ (1 male); Prescott, AZ (5 males; "AZ" (3 males, 3 females); Silver City NM (1 male, 1 female); "NM" (3 males, 3 females); no locality specified (1 male, 2 females).

\section{Literature Cited}

CASEY, T. L.

1915. A Revision of the American species of Rutelinae, Dynastinae, and Cetoniinae. Memoirs on the Coleoptera 6: 1-394.

ENDRÖDI, S.

1985. The Dynastinae of the World. W. Junk, the Hague. 800 pp. +46 plates. HARDY, A. R.

1972. A Brief Revision of the North and Central American Species of Megasoma (Coleoptera: Scarabaeidae). The Canadian Entomologist 104: 765-777.

HORN, G. H.

1870. Contributions to the Coleopterology of the United States. Transactions of the American Entomological Society 3: 69-134.

1894. The Coleoptera of Baja California. Proceedings of the California Academy of Sciences 2:4: 302-449.

LeConTE, J. L.

1861. Notes on the coleopterous fauna of Lower California. Proceedings of the Academy of Natural Sciences of Philadelphia 13: 335-338.

SAYLOR, L. W.

1948. Contributions towards a knowledge of the insect fauna of Lower California, Number 10, Coleoptera: Scarabaeidae. Proceedings of the California Academy of Sciences 4:24:10: 337-374. 

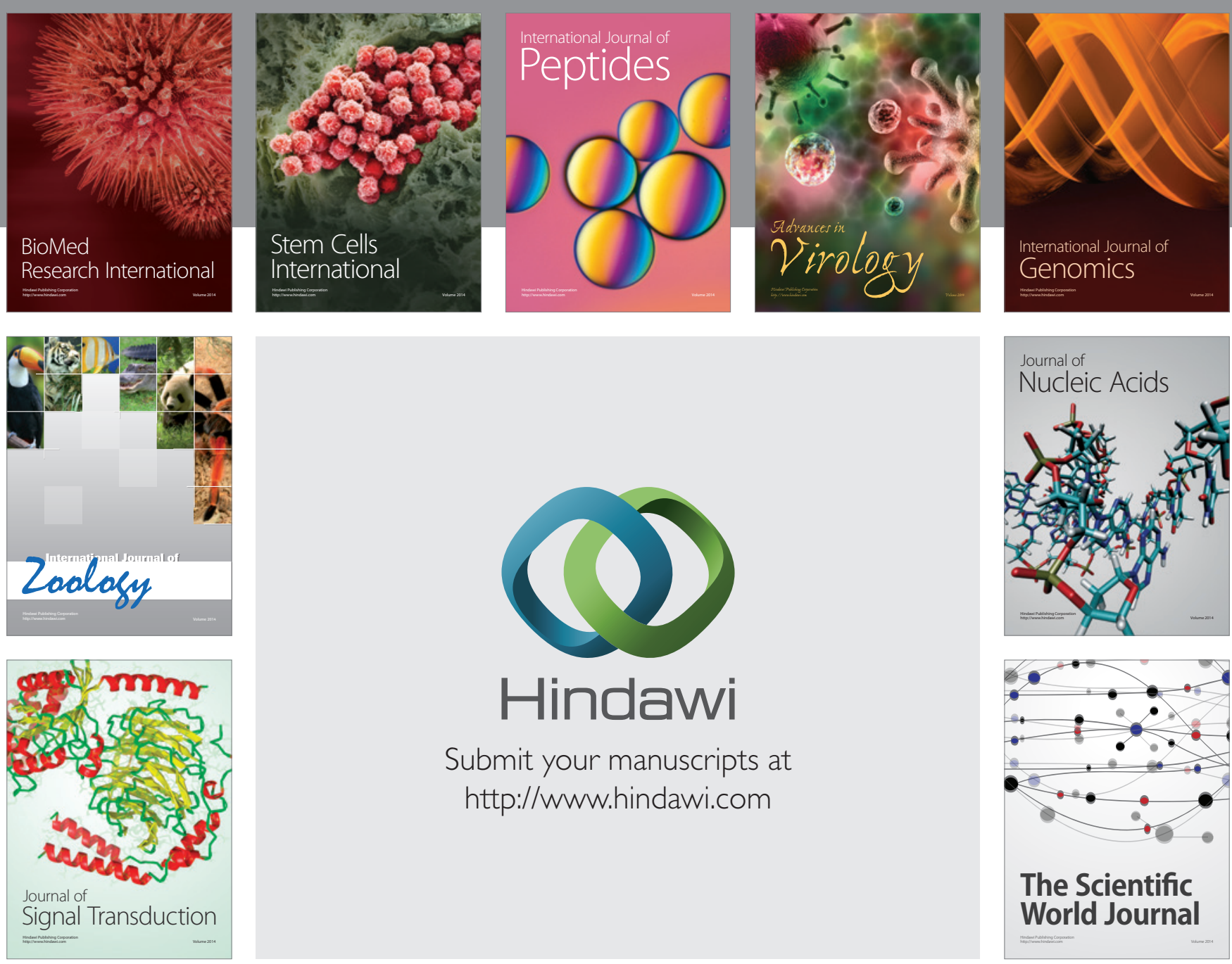

Submit your manuscripts at

http://www.hindawi.com
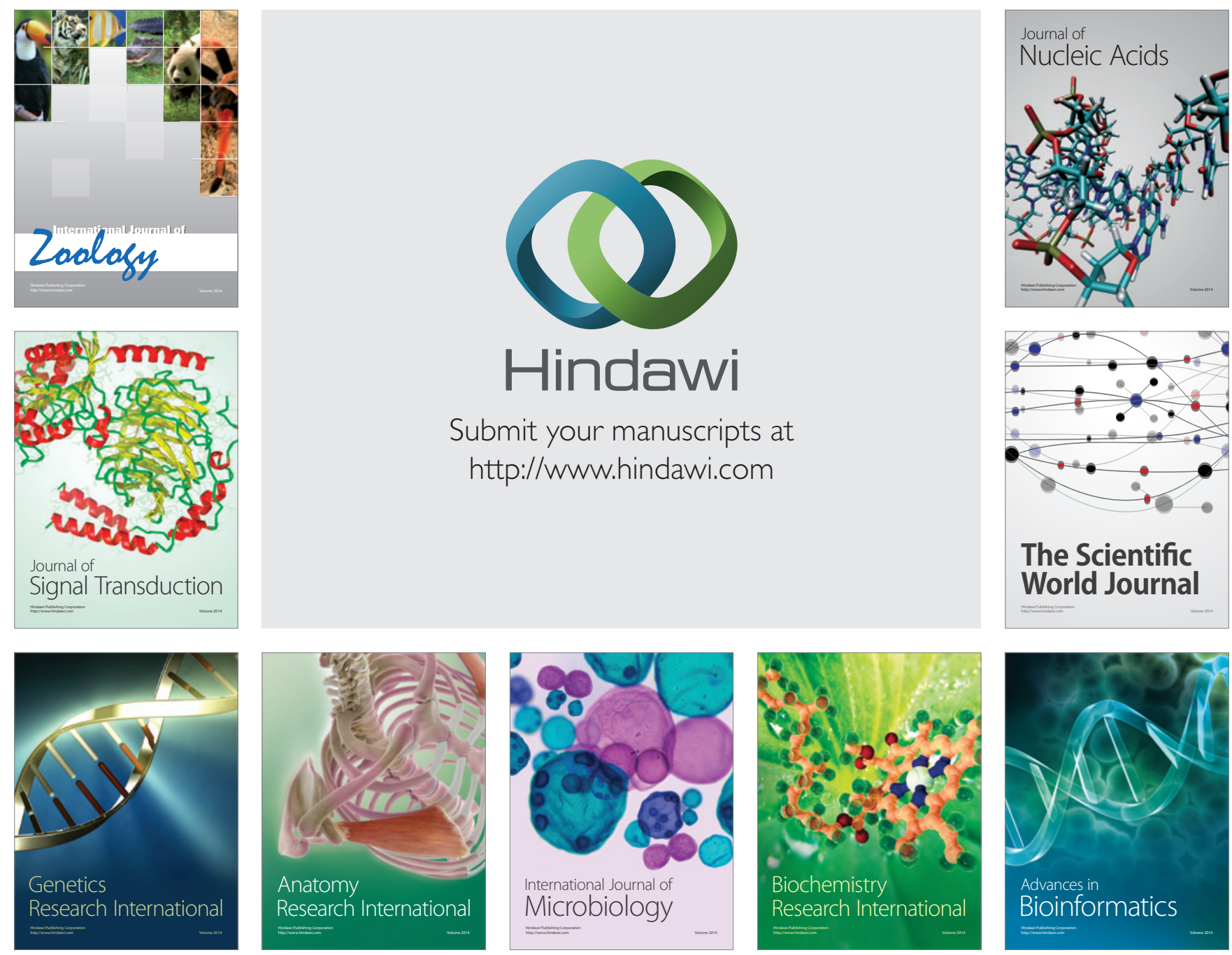

The Scientific World Journal
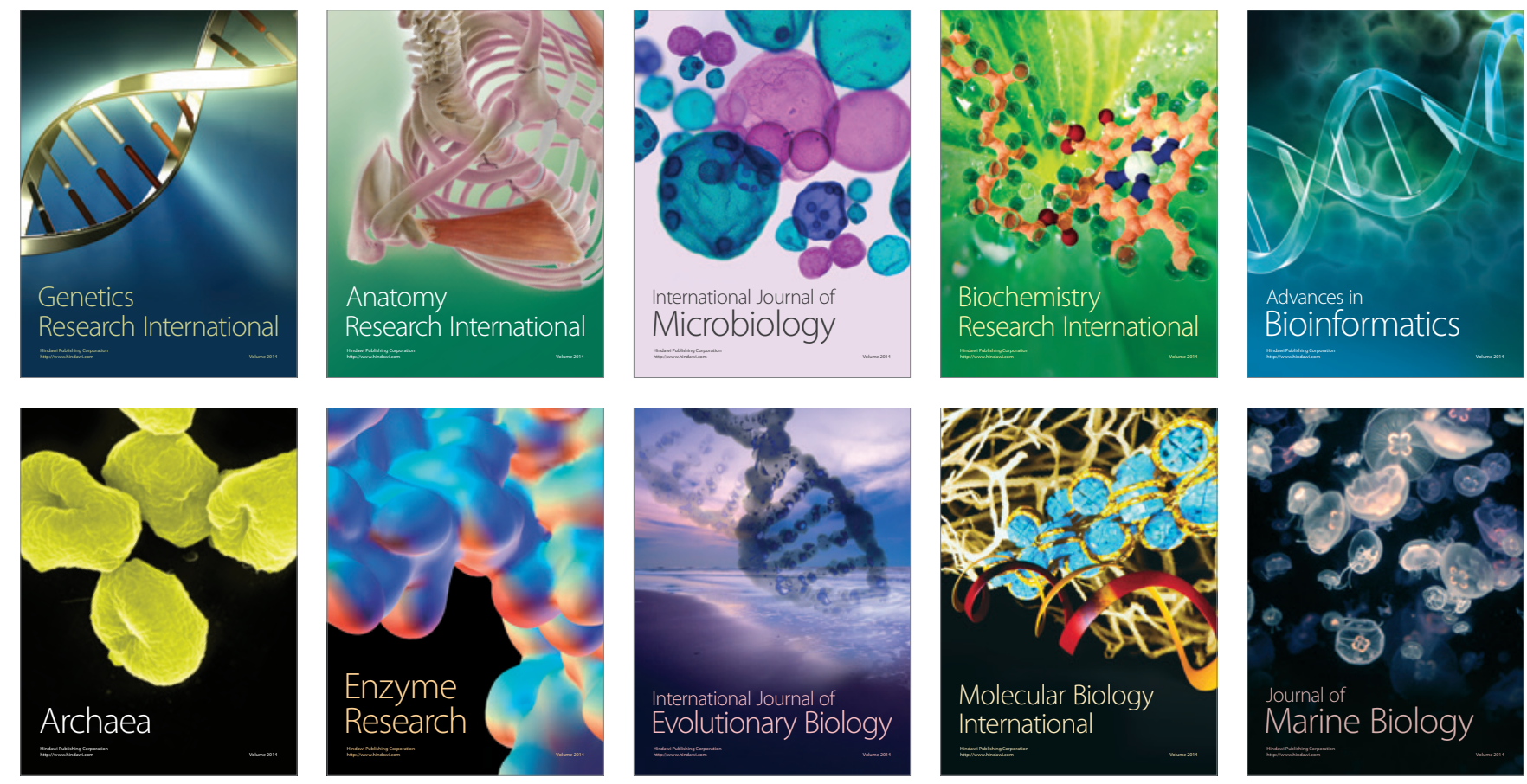